The experiments which have demonstrated the formation of polynucleotides from cyclic mononucleotides have some bearing on the present views of RNA structure. The hydrolytic conditions used by Markham \& Smith (1952a-c) were quite favourable for synthetic reactions to manifest themselves, and it is probable that part, at least, of the cyclic dinucleotides reported by these workers as occurring in partial ribonuclease digests of RNA's was synthetic in origin. It is thus impossible to conclude that any particular pair of pyrimidine nucleotide residues are adjacent in the RNA molecules, although from a statistical point of view it is certain that regions must occur where several pyrimidine nucleotide residues are adjacent. As far as the other polynucleotides which are liberated from RNA by ribonuclease are concerned, it should be noted that this enzyme appears to be unable to synthesize compounds which it cannot degrade, and so there is no reason to suspect that substances isolated from exhaustively digested RNA are artifacts.

\section{SUMMARY}

1. Ribonuclease was found to catalyse the synthesis of polynucleotides from cyclic cytidylic acid (cytidine-2':3' phosphate). Evidence for synthesis of the dinucleotide, cyclic dinucleotide and cyclic trinucleotide has been presented. With cytidine also present as an acceptor molecule, two other reaction products were isolated. They were the dinucleoside phosphate and the trinucleoside diphosphate. Under certain conditions the amount of synthesis exceeded by far the extent of hydrolysis of the cyclic mononucleotides. Uridine derivatives were also active in these reactions.

2. In the transfer reactions catalysed by ribonuclease, adenosine and adenosine- $2^{\prime}: 3^{\prime}$ phosphate could also be used as acceptor molecules. In general, the nucleoside-3' phosphates were very poor as acceptors.

3. A phosphodiesterase preparation purified from spleen was observed to catalyse exchange reactions involving ribopolynucleotides. This enzyme preparation, however, was inactive with cyclic nucleotides.

4. The possible significance of these reactions in ribonucleic acid interconversions has been discussed.

One of us (L.A.H.) participated in this work as a member of the National Institutes of Health, Bethesda, temporarily assigned to the Molteno Institute. Grateful acknowledgement is made to the John Simon Guggenheim Memorial Foundation for a Fellowship (to L.A.H.), to the American Cancer Society for a Travel Aid Grant (to L.A.H.) and to the Commonwealth of Australia Scientific and Industrial Research Organization for a Fellowship (to P.R.W.).

\section{REFERENCES}

Allen, R. J. L. (1940). Biochem. J. 34, 858.

Brown, D. M., Magrath, D. I. \& Todd, A. R. (1952). J. chem. Soc. p. 2708.

Heppel, L. A., Markham, R. \& Hilmoe, R. J. (1953). Nature, Lond., 171, 1151.

Heppel, L. A. \& Whitfeld, P. R. (1955). Biochem. J. 60, 1. Heppel, L. A., Whitfeld, P. R. \& Markham, R. (1954). Biochem. J. 56, iii.

Lythgoe, B. \& Todd, A. R. (1944). J. chem. Soc. p. 592. Markham, R. \& Smith, J. D. (1951). Biochem. J. 49, 401. Markham, R. \& Smith, J. D. (1952a). Biochem. J. 52, 552. Markham, R. \& Smith, J. D. (1952b). Biochem. J. 52, 558. Markham, R. \& Smith, J. D. (1952c). Biochem. J. 52, 565. Smith, J. D. \& Markham, R. (1950). Biochem. J. 46, 509. Volkin, E. \& Cohn, W. E. (1953). J. biol. Chem. 205, 767. Whitfeld, P. R. (1954). Biochem. J. 58, 390.

Whitfeld, P. R., Heppel, L. A. \& Markham, R. (1955). Biochem. J. 60, 15.

\title{
The Enzymic Hydrolysis of Ribonucleoside-2': $3^{\prime}$ Phosphates
}

\author{
By P. R. WHITFELD, L. A. HEPPEL* AND R. MARKHAM \\ Agricultural Research Council Plant Virus Research Unit, Molteno Institute, University of Cambridge
}

(Received 16 September 1954)

The 2':3' phosphate esters of ribonucleosides (referred to as cyclic nucleotides in this paper) arise as intermediate products in the course of hydrolysis of ribonucleic acids (RNA) by pancreatic ribonuclease and by dilute alkali. The mechanism of action of ribonuclease has been discussed recently by several authors (Markham \& Smith, 1952b, c; Merrifield \& Woolley, 1952; Brown \& Todd, 1953;

* Present address: National Institutes of Health, Bethesda, Md., U.S.A.
Volkin \& Cohn, 1953). The enzyme hydrolyses pyrimidine cyclic nucleotides at a slow rate (Markham \& Smith, 1952b) to produce exclusively pyrimidine nucleoside-3' phosphates ; thus, cytidine$2^{\prime}: 3^{\prime}$ phosphate is split to yield only cytidine-3' phosphate (Brown, Dekker \& Todd, 1952). In contrast, alkali degrades the same cyclic nucleotide to give a mixture of cytidine-2' phosphate and cytidine-3' phosphate. A mechanism for the alkaline hydrolysis of RNA which involves the 
formation of cyclic nucleotides as intermediates has been proposed (Brown \& Todd, 1952) to account for the production of the isomeric nucleoside-2' phosphates and nucleoside-3' phosphates, which were originally described by Cohn (1950), Carter (1950) and later by Loring, Luthy, Bortner \& Levy (1950).

Other enzymic studies have given results in agreement with those obtained with ribonuclease; that is, nucleoside-3' phosphates rather than nucleoside-2' phosphates have been found as the hydrolytic end-products derived from ribopolynucleotides. Volkin \& Cohn (1952) found that spleen extracts prepared according to Maver \& Greco (1949) split RNA to give mainly nucleoside-3' phosphates and this was confirmed by Heppel, Markham \& Hilmoe (1953) with a purified spleen phosphodiesterase preparation. Dekker (1954) observed that snake-venom phosphodiesterase hydrolyses cyclic mononucleotides to form nucleoside-3' phosphates. From these results it might be concluded that nucleoside-2' phosphates arise only as artifacts produced by alkaline or acidic hydrolysis of cyclic nucleotides.

However, we now have evidence that certain enzyme reactions can give rise to nucleoside-2' phosphates; for instance, a spleen phosphodiesterase preparation hydrolyses cyclic nucleotides to give only the 2 ' isomers of the nucleotides. The possible importance of the latter compounds in biological systems can therefore no longer be disregarded.

\section{MATERIALS AND METHODS}

Cytidine-containing compouinds. Cytidine-2':3' phosphate was isolated from ribonuclease digests of yeast RNA according to the method of Markham \& Smith (1952a). It was also synthesized chemically according to Brown, Magrath \& Todd (1952). The cyclic dinucleotide of cytidylic acid, and dicytidine phosphate were synthesized enzymically with ribonuclease (Heppel, Whitfeld \& Markham, 1955).

Purine cyclic nucleotides and cyclic diadenylic acid. Commercial RNA (yeast) was digested exhaustively with pancreatic ribonuclease (Markham \& Smith, 1952c) and dialysed in cellophan tubing against running tap water for 24-36 $\mathrm{hr}$. The non-dialysable material was precipitated by the addition of ethanol (3 vol.) and dried. A solution of this 'core' containing 0.1-1.0 g. in $25 \mathrm{ml}$. of water was placed in a cellophan tube together with 1-2 g. of $\mathrm{BaCO}_{3}$ and the tube immersed in boiling water $(200 \mathrm{ml}$.) for $30-60 \mathrm{~min}$. The material outside the sac was then concentrated in vacuo, and chromatographed on Whatman no. 3MM paper in solvent 1 (see below). Three ultra violet-absorbing bands which had $R_{\boldsymbol{p}}$ values greater than that of cytidylic acid, and which corresponded with the bands $5,5 a$ and 6 described by Markham \& Smith (1952b), were found. Because ribonuclease had broken all the pyrimidine nucleoside-3' phosphate ester links present in the starting material the 'core' can only give rise to two cyclic mononucleotides on hydrolysis, namely cyclic guanylic acid and cyclic adenylic acid. These are consequently found in an uncontaminated state in bands $5 a$ and 6 . Band 5 is in the position in which cyclic dinucleotides not containing guanine are to be found. The only compound of this type which could arise from the hydrolysis of 'core' is cyclic diadenylic acid. The first two substances were identified by procedures already described (Markham \& Smith, 1952a). Cyclic diadenylic acid, which has not been reported previously, was identified by the procedures described by Markham \& Smith (1952b) and by Heppel et al. (1955).

Nucleotide benzyl esters. Adenosine-3' benzyl phosphate and cytidine-3' benzyl phosphate were synthesized chemically (Brown \& Todd, 1953; Brown, Heppel \& Hilmoe, 1954).

The dinucleotide, adenylyl-uridylic acid, was isolated from a ribonuclease digest of RNA by the method of Markham \& Smith (1952b).

Enzymes. Crystalline ribonuclease was obtained from pancreas (Kunitz, 1940).

The phosphodiesterase fraction from calf spleen was prepared as described by Heppel \& Whitfeld (1955), and the calf intestinal mucosa phosphatase preparation was made according to Brown et al. (1954). A more detailed description of both procedures is in press (Hilmoe \& Heppel, 1955).

Dried Crotalus adamanteus (rattlesnake) venom was obtained from Ross Allen's Reptile Institute, Silver Springs, Florida, U.S.A.

Rye grass phosphatase was a crude preparation corresponding with the first ammonium sulphate fraction in the purification of $3^{\prime}$-nucleotidase (Shuster \& Kaplan, 1953) and was a gift from Drs L. Shuster and N. O. Kaplan.

Paper chromatography. The methods employed were those described by Markham \& Smith $(1952 a, b)$. The solvent systems used were: Solvent 1: 70\% isopropanol-water (v/v) with $\mathrm{NH}_{3}$ in the vapour phase. Solvent 2 : sat. $\left(\mathrm{NH}_{4}\right)_{2} \mathrm{SO}_{4}$ in water-isopropanol-M sodium acetate $(80: 2: 18, v / v / v)$.

Ion-exchange chromatography. The isomers of cytidylic acid were separated on a column of Dowex-1 resin (formate form, $10 \%$ cross-linked, $10 \mathrm{~cm}$. $\times 1.07$ sq.cm.) (Cohn; 1950; Brown, Dekker \& Todd, 1952). The cytidylic acid (eluted from a paper chromatogram) was applied in solution in water adjusted to $\mathrm{pH} 9$ with $\mathrm{NH}_{4} \mathrm{OH}$. The column was washed with $0.005 \mathrm{M}$ ammonium formate $(100 \mathrm{ml}$.) and then with water $(100 \mathrm{ml}$.). Elution was effected with $0.02 \mathrm{~N}$ formic acid at a flow rate of $0.8 \mathrm{ml}$./min., taking $16 \mathrm{ml}$. fractions.

The same separation was also achieved by paper chromatography in solvent 2 , in which cytidine-3' $3^{\prime}$ phosphate has an $R_{F}$ value appreciably less than that of cytidine-2' phosphate. Before making use of this means of separation, uridylic acid isomers if present have to be removed by paper electrophoresis at pH 3.5 because they overlap with the $3^{\prime}$. isomer of cytidylic acid.

\section{RESULTS}

\section{Specificity of the spleen phosphodiesterase preparation}

Adenosine-3' benzyl phosphate, cytidine-3' benzyl phosphate, adenylyl-uridylic acid, cytidylyl-cytidine and RNA 'core' were all treated with a preparation of spleen phosphodiesterase which contained $9 \mathrm{mg}$. of protein $/ \mathrm{ml}$. The conditions of incubation were similar for each compound $(0.03 \mathrm{ml}$. 
of $0.05 \mathrm{M}$ phosphate buffer (Sørensen), pH 7.4, containing $0.3-1.0 \mu$ mole of substrate, and $0.03-$ $0.07 \mathrm{ml}$. of enzyme). Incubations were at $37^{\circ}$ for $4 \mathrm{hr}$. for the first two compounds, $1 \mathrm{hr}$. for the third and $7 \mathrm{hr}$. for the last two. These times were sufficient for complete hydrolysis to the nucleotide to have taken place as shown by chromatography in solvent 1. Samples were chromatographed in solvent 2 , and the nucleotides formed were all found to be nucleoside-3' phosphates. In the case of the 'core', of course, the pyrimidine nucleotide residues were terminal and had already been left as the 3 '-phosphates by the ribonuclease action.

Adenosine-2': $3^{\prime}$ phosphate, guanosine-2' $: 3^{\prime}$ phosphate and cytidine-2': $3^{\prime}$ phosphate were each incubated, under conditions similar to the above for 2,3 and $6 \mathrm{hr}$. respectively, with $0.07 \mathrm{ml}$. of the spleen enzyme preparation. In each case the product obtained was the corresponding nucleoside-2' phosphate. Control incubations were carried out without adding the enzyme but otherwise under the same conditions.

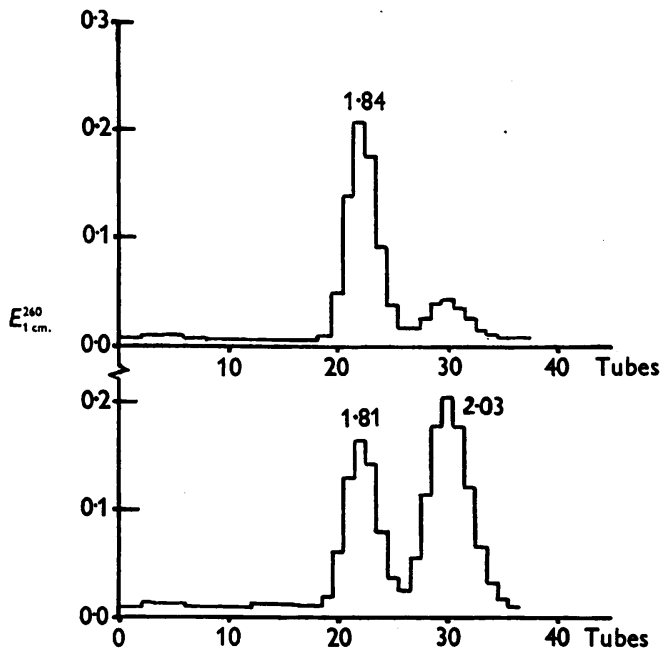

Fig. 1. Ion-exchange chromatography of cytidylic acid formed from cytidine-2':3' phosphate by the spleen phosphodiesterase preparation. Numbers above the peaks represent the ratio of the optical density values at $280 \mathrm{~m} \mu$./260 $\mathrm{m} \mu$., which was constant over each peak. More than $95 \%$ of the ultraviolet-absorbing material applied to the column was recovered. Upper diagram: cytidylic acid derived enzymically from cytidine-2':3' phosphate. Lower diagram: commercial mixture of cytidine-2' phosphate (left peak) and cytidine-3' phosphate (right peak).

Fig. 1 shows the ion-exchange chromatogram of the product resulting from the hydrolysis of cytidine-2':3 phosphate under the conditions mentioned above. The cytidylic acid was first isolated from the reaction mixture by paper chromatography in solvent 1 before it was applied to the ion-exchange column. The column had been calibrated previously by chromatographing a mixture of cytidine-2' and cytidine-3' phosphates. It can be seen that the major product of the enzyme action is cytidine-2' phosphate. The small quantity of the $3^{\prime}$ - isomer appearing may originate from spontaneous breakdown of the starting material.

As this enzyme preparation evidently acted differently towards these two types of phosphodiesters, it was of interest to examine its effect on substances containing both types of grouping. Accordingly, cyclic diadenylic acid, which is the ( $5^{\prime}$-adenosine-2': $3^{\prime}$ phosphate) ester of adenosine-3' phosphate, was incubated with the spleen enzyme preparation under the same conditions as above until the reaction was complete. The product was chromatographed in solvent 2 and was found to be a mixture of adenosine-2' phosphate and adenosine$3^{\prime}$ phosphate in the molar ratio of $0.91: 1$. In a similar experiment the cyclic dinucleotide of cytidylic acid yielded cytidine-2' phosphate and cytidine $-3^{\prime}$ phosphate in the molar ratio of $1 \cdot 1: 1$.

\section{Specificity of other phosphodiesterase preparations}

Calf intestinal mucosa phosphodiesterase. The calf intestinal mucosa preparation was found to form only mononucleoside-3' phosphates from ribopolynucleotides. This same preparation has been shown to hydrolyse adenosine- $3^{\prime}$ benzyl phosphate to give adenosine-3' phosphate (Brown et al. 1954).

When cytidine-2' $: 3^{\prime}$ phosphate was incubated with this enzyme under the conditions given in Fig. 2 the product was found to be cytidine-3' phosphate almost exclusively. Adenosine-2': $3^{\prime}$ phosphate and guanosine-2': $3^{\prime}$ phosphate were both split by the intestinal mucosa preparation to give mainly the corresponding nucleoside-3' ${ }^{\prime}$ phosphate. However, in the case of the purine cyclic nucleotides substantial amounts (10-20\%) of the nucleoside-2' phosphates were formed as well, possibly owing to the presence in the preparation of two different enzymes having activity towards cyclic nucleotides.

Rye grass phosphodiesterase. Adenosine-2':3' phosphate ( $1 \mu \mathrm{mole}$ ) was incubated for $4 \mathrm{hr}$. at $37^{\circ}$ with $0.04 \mathrm{ml}$. of rye grass preparation ( $\equiv 40 \mu \mathrm{g}$. of protein) and $0.02 \mathrm{ml}$. of $0.05 \mathrm{M}$ phosphate buffer, $\mathrm{pH} 7 \cdot 2$, the total volume being $0 \cdot 1 \mathrm{ml}$. The products were chromatographed in solvent 2. Approximately equivalent amounts of adenosine and adenosine-2' phosphate were formed. Presumably the former arose by way of adenosine-3' phosphate which is then readily dephosphorylated by the $3^{\prime}$-nucleotidase present in the preparation.

Snake venom. Dekker (1954) has reported that snake (Crotalus adamanteus) venom hydrolyses cyclic nucleotides to give nucleoside-3' phosphates. 
Dr J. D. Smith has made similar observations (private communication), and we have confirmed these findings using adenosine-2':3' phosphate and cytidine-2':3' phosphate as substrates.

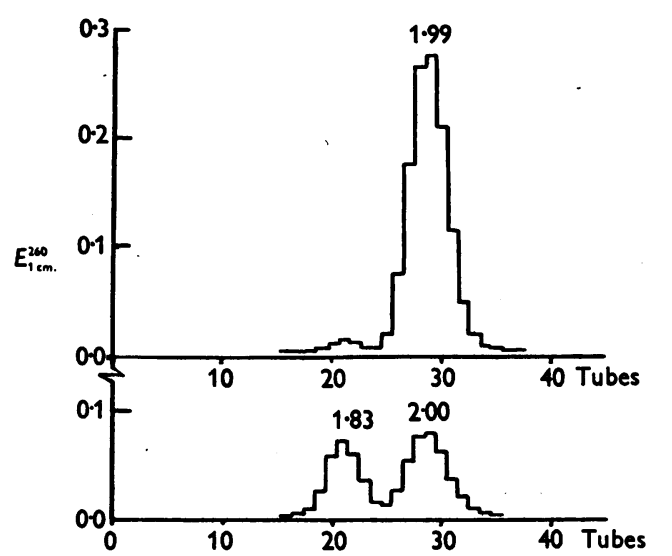

Fig. 2. Ion-exchange chromatography of cytidylic acid formed from cytidine-2':3' phosphate by an enzyme fraction from calf intestinal mucosa. A mixture consisting of $0.1 \mathrm{ml}$. of intestinal mucosa enzyme ( $0.9 \mathrm{mg}$. of protein), $0.05 \mathrm{ml}$. of $0.5 \mathrm{M}$ Sørensen's phosphate buffer, $\mathrm{pH} \mathrm{7.4}$, $0.05 \mathrm{ml}$. of water and $5 \mathrm{mg}$. of cytidine-2':3' phosphate was incubated at $37^{\circ}$ for $24 \mathrm{hr}$., when hydrolysis was nearly complete. Chloroform was added to prevent bacterial growth. The mixture was chromatographed in solvent 1, and the band corresponding to cytidylic acid was eluted and subjected to column chromatography. Over $95 \%$ of the ultraviolet-absorbing material applied to the column was recovered. Upper diagram: cytidylic acid derived enzymically from cytidine-2':3' phosphate. Lower diagram: commercial mixture of cytidine-2' phosphate (left peak) and cytidine-3' phosphate (right peak).

\section{DISCUSSION}

Nucleoside-2' phosphates have hitherto been considered to be only artifacts resulting from acidic or alkaline hydrolysis of ribopolynucleotides. We have now shown that they may arise by enzymic hydrolysis of nucleotides which contain a $2^{\prime}: 3^{\prime}$ cyclic phosphate group.

Of the various enzyme preparations which have so far been examined, the phosphodiesterase fraction of spleen hydrolyses cyclic nucleotides to give almost exclusively nucleoside-2' phosphates, whereas the calf intestinal mucosa and rye grass fractions hydrolyse cyclic nucleotides to yield mainly nucleoside-3' phosphates, although substantial amounts of nucleoside-2' phosphates are also formed. In the case of the latter enzyme preparations, it would appear either that the phosphodiesterase responsible for the splitting of the $2^{\prime}: 3^{\prime}$-phosphodiester bond is non-specific in that it can attack the ester link both on $\mathrm{C}_{\left(\mathbf{3}^{\prime}\right)}$ and on $\mathrm{C}_{\left(\mathbf{(}^{\prime}\right)}$, or that there are present in the tissue fractions two phosphodiesterases which have different specificities. The latter explanation is perhaps the more probable since both enzyme preparations are relatively crude, having been fractionated no more than twice. It should be pointed out that, if there are two phosphodiesterases in the intestinal mucosa preparation and in the rye grass preparation, the results obtained in the present investigation would not necessarily be a true representation of the relative amounts of the two enzymes in the unfractionated tissues.

It is conceivable that the enzyme in the intestinal mucosa preparation which is responsible for the formation of nucleoside-2' phosphates from cyclic guanylic acid and cyclic adenylic acid is the same as the enzyme present in the spleen phosphodiesterase preparation.

The phosphodiesterase preparation from spleen degrades dinucleotides, RNA 'core', and benzyl esters of ribomononucleotides to give rise, in each case, exclusively to nucleoside-3' phosphates (Heppel et al. 1953; Brown et al. 1954). The fact that the same enzyme preparation hydrolyses nucleoside-2':3' phosphates to nucleoside-2' phosphates indicates that there may be more than one phosphodiesterase present in the fraction. Evidence in support of this has been obtained by R. J. Hilmoe (private communication), who has succeeded in effecting a partial separation of the two types of diesterase activity.

It has been suggested (Heppel et al. 1953; Heppel \& Whitfeld, 1955) that the spleen phosphodiesterese preparation, unlike ribonuclease, hydrolyses ribopolynucleotides to nucleotides without the production of cyclic nucleotides as intermediates. The results reported in this paper confirm this suggestion. If cyclic nucleotides were formed as intermediates during the hydrolysis of the ribopolynucleotides, then they would be split to give nucleoside-2' phosphates. The hydrolysis products of the spleen phosphodiesterase preparation acting on ribopolynucleotides are nucleoside-3' phosphates only (Heppel et al. 1953).

The demonstration of the ability of certain enzyme reactions to produce nucleoside-2' phosphates has a double significance. In the first place, the 2 ' - isomers of the nucleotides can now no longer be considered incapable of playing a part in biological systems. In this respect it is of interest to note that adenosine-2' phosphate shows biological activity in the pyridine nucleotide transhydrogenase system of Pseudomonas (Kaplan, Colowick, Neufeld \& Ciotti, 1953), whereas adenosine-3' phosphate and adenosine-5' phosphate are inactive.

Secondly, whenever nucleoside-2' phosphates are isolated from tissues, the possibility that they arise 
from the enzymic hydrolysis of cyclic nucleotides must not be overlooked. The presence in several RNAs of purine nucleotide residues containing a $2^{\prime}: 3^{\prime}$-cyclic phosphate group has been shown by Markham \& Smith (1952c). Any such groups would be converted by the spleen phosphodiesterase into nucleoside-2' phosphates. Furthermore, the action of ribonuclease on RNA is known to produce large quantities of pyrimidine cyclic nucleotides and cyclic dinucleotides which are then only slowly hydrolysed to nucleoside-3' phosphates (Markham \& Smith, 1952a-c). Obviously, the combined action of ribonuclease and spleen phosphodiesterase on RNA could give rise to large amounts of nucleoside-2' phosphates.

The only naturally occurring compound of biological interest which is known to contain a nucleoside-2' phosphate moiety is triphosphopyridine nucleotide (Kornberg \& Pricer, 1950; Wang, Shuster \& Kaplan, 1954). It was considered that a re-examination of the structure of this molecule might be worthwhile and the results of such an investigation are the subject of the succeeding communication.

\section{SUMMARY}

1. It has been shown that certain enzymes can hydrolyse nucleoside-2': $3^{\prime}$ phosphates to give rise to the corresponding nucleoside-2' phosphates. An enzyme preparation from spleen which hydrolysed internucleotidic phosphodiester bonds to give mainly nucleoside-3' phosphates was shown to form nucleoside-2' phosphates from cyclic nucleotides.

2. Nucleoside-2' phosphates were formed from cyclic nucleotides by a rye grass preparation. In this reaction, however, nucleoside-3' phosphates also were produced and then dephosphorylated to give rise to nucleosides.

3. Other phosphodiesterase preparations from intestinal mucosa and from snake venom have also been examined with respect to their specificity towards two types of phosphodiester bonds.
One of us (L.A.H.) participated in this work as a member of the National Institutes of Health, Bethesda, temporarily assigned to the Molteno Institute. Grateful acknowledgement is made to the John Simon Guggenheim Memorial Foundation for a Fellowship (to L.A.H.), to the American Cancer Society for a Travel Aid Grant (to L.A.H.) and to the Commonwealth of Australia Scientific and Industrial Research Organization for a Fellowship (to P.R.W.).

\section{REFERENCES}

Brown, D. M., Dekker, C. A. \& Todd, A. R. (1952). J. chem. Soc. p. 2715.

Brown, D. M., Heppel, L. A. \& Hilmoe, R. J. (1954). J. chem. Soc. p. 40.

Brown, D. M., Magrath, D. I. \& Todd, A. R. (1952). J.chem. Soc. p. 2708.

Brown, D. M. \& Todd, A. R. (1952). J. chem. Soc. p. 52.

Brown, D. M. \& Todd, A. R. (1953). J. chem. Soc. p. 2040.

Carter, C. E. (1950). J. Amer. chem. Soc. 72, 1466.

Cohn, W. E. (1950). J. Amer. chem. Soc. 72, 2811.

Dekker, C. A. (1954). Fed. Proc. 13, 197.

Heppel, L. A., Markham, R. \& Hilmoe, R. J. (1953). Nature, Lond., 171, 1151.

Heppel, L. A. \& Whitfeld, P. R. (1955). Biochem. J. 60, 1.

Heppel, L. A., Whitfeld, P. R. \& Markham, R. (1955). Biochem. J. 60, 8.

Hilmoe, R. J. \& Heppel, L. A. (1955). Methods in Enzymology. Vol. 2, section 90. New York: Academic Press Inc.

Kaplan, N. O., Colowick, S. P., Neufeld, E. F. \& Ciotti, M. M. (1953). J. biol. Chem. 205, 17.

Kornberg, A. \& Pricer, W. E. jun. (1950). J. biol. Chem. 186, 557.

Kunitz, M. (1940). J. gen. Physiol. 24, 15.

Loring, H. S., Luthy, N. O., Bortner, H. W. \& Levy, L. W. (1950). J. Amer. chem. Soc. 72, 2811.

Markham, R. \& Smith, J. D. (1952a). Biochem. J. 52, 552. Markham, R. \& Smith, J. D. (1952b). Biochem. J. 52, 558. Markham, R. \& Smith, J. D. (1952c). Biochem. J. 52, 565. Maver, M. E. \& Greco, A. E. (1949). J. biol. Chem. 181, 861. Merrifield, R. B. \& Woolley, D. W. (1952). J.biol.Chem.197, 521.

Shuster, L. \& Kaplan, N. O. (1953). J. biol. Chem. 201, 535. Volkin, E. \& Cohn, W. E. (1952). Fed. Proc. 11, 303.

Volkin, E. \& Cohn, W. E. (1953). J. biol. Chem. 205, 767.

Wang, T. P., Shuster, L. \& Kaplan, N. O. (1954). J. biol. Chem. 206, 299.

\title{
A Note on the Structure of Triphosphopyridine Nucleotide
}

\author{
By L. A. HEPPEL,* P. R. WHITFELD AND R. MARKHAM \\ Agricultural Research Council Plant Virus Research Unit, Molteno Institute, University of Cambridge
}

\section{(Received 16 September 1954)}

Kornberg \& Pricer (1950b) have proposed a structure for triphosphopyridine nucleotide (TPN) which contains a monoester phosphate group attached to $\mathrm{C}_{\left(2^{\prime}\right)}$ of the adenosine moiety (Fig. $1 a$ ). Their evidence is based on the fact that the adeno-

* Present address: National Institutes of Health, Bethesda, Md., U.S.A. sine diphosphate derived from TPN by hydrolysis with a nucleotide pyrophosphatase (Kornberg \& Pricer, $1950 a$ ) could be partially dephosphorylated by a specific adenosine- $5^{\prime}$ phosphatase from potato to give adenosine-2' phosphate. A similar conclusion was reached by Kaplan, Colowick \& Ciotti (1952), who made use of a specific deaminase. Wang, 